\title{
Assessment of Coalbed Gas Resources in the Kutei and Barito Basin Provinces, Indonesia, 2018
}

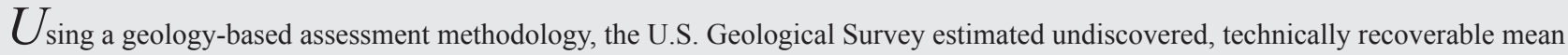
resources of 10.7 trillion cubic feet of potential coalbed gas resources in the Kutei and Barito Basin Provinces of Indonesia.

\section{Introduction}

The U.S. Geological Survey (USGS) quantitatively assessed the potential for undiscovered, technically recoverable continuous (unconventional) coalbed gas resources in the Kutei and Barito Basin Provinces of Indonesia (fig. 1). Miocene coals in the Kutei and Barito Basin Provinces form part of a regressive clastic wedge sourced from uplifted areas in western Borneo (Moss and Chambers, 1999; Witts and others, 2011). Clastic sediments of this wedge prograded to the east and southeast within fluvial-deltaic and marginal marine environments with extensive coals (Paterson and others, 1997; Davis and others, 2007; Widodo and others, 2010). The extent, thickness, and thermal maturation of coals have been documented in both basins (Adhi and others, 2004; Sapiie and others, 2014; Friederich and others, 2016; Putra and others, 2016). Drilling and testing for coalbed gas has occurred in the Barito Basin Province, where coals of the Miocene Warukin Formation are the primary exploration target (De Man and others, 2012; Putra and others, 2016). The primary coalbed gas reservoirs in the Kutei Basin are coals of the Miocene Balikpapan Formation (Satyana and others, 1999; Pramudhita and others, 2009), which have not been drilled or tested to the extent of Warukin coals in the Barito Basin.

\section{Total Petroleum Systems and Assessment Units}

For potential coalbed gas resources in the Kutei Basin Province, the USGS defined a Kutei Neogene Coal Total Petroleum System (TPS) and Kutei Neogene Coalbed Gas Assessment Unit (AU) within this TPS. The Barito Neogene Coal TPS was defined in the Barito Basin Province with a Barito Neogene Coalbed Gas AU. Shallow Neogene coals in both basins are generally thermally immature with vitrinite reflectance of less than 0.5 percent (Haris and others, 2010), contain Type III kerogen, have hydrogen index values of as much as 260 milligrams of hydrocarbon per gram of organic carbon, and have net coal thickness of as much as 60 meters (Davis and others, 2007). The geologic model for this assessment is similar for coalbed gas accumulations in both the Kutei and Barito Basin Provinces. Coals of the Neogene regressive clastic wedge were deposited across large areas of both basins. Shallow burial generally left the coals thermally immature with respect to gas generation. However, bacterial activity acting on shallow coals produced biogenic gas, which was adsorbed and retained within the coal cleat systems (De Man and others, 2012). The geologic model for both TPSs includes the possibility that some thermogenic gas is present within the deeper, more thermally mature Neogene coals (Haris and others, 2010). Vertical wells were used in the modeling of potential coalbed gas resources.

Assessment input data are summarized in table 1. Input data for drainage areas, success ratios, and estimated ultimate recoveries are taken from geologic analogs in the United States, particularly the coals in the Powder River Basin (Flores, 2004).

\section{Undiscovered Resources Summary}

The USGS quantitatively assessed coalbed gas resources in two assessment units (table 2) in the Kutei and Barito Basin Provinces of Indonesia. For undiscovered, technically recoverable coalbed gas resources, the mean totals are 10,738 billion cubic feet of gas (BCFG), or 10.7 trillion cubic feet of gas, with an F95-F5 fractile range from 2,525 to $22,759 \mathrm{BCFG}$. Of the mean total of $10,738 \mathrm{BCFG}$ (coalbed), 6,753 BCFG, or 63 percent, is estimated to be in the Kutei Neogene Coalbed Gas AU, and 3,985 BCFG (coalbed), or 37 percent, is estimated to be in the Barito Neogene Coalbed Gas AU.

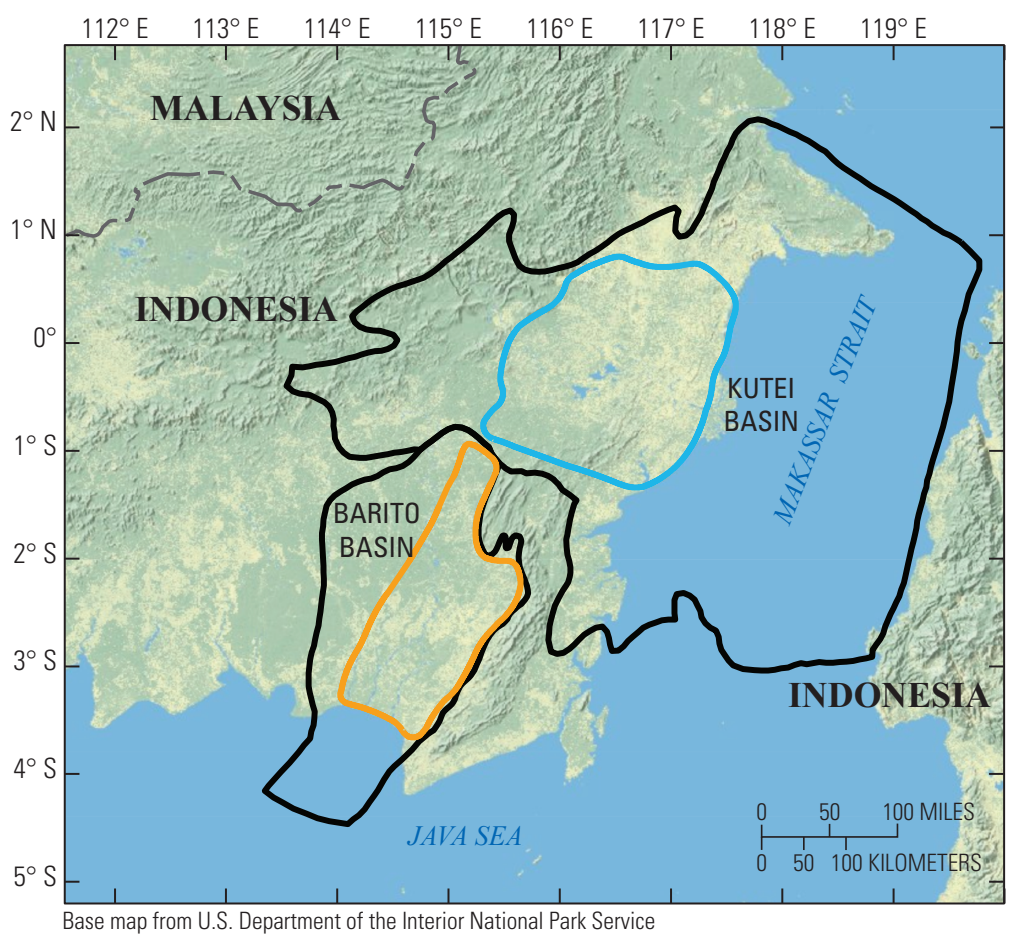

\section{EXPLANATION}
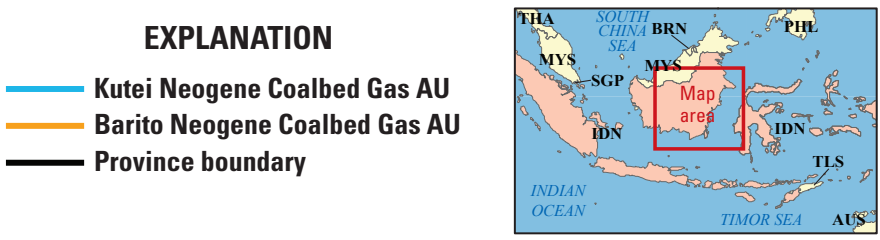

Figure 1. Map showing the two coalbed gas assessment units (AUs) in the Kutei and Barito Basin Provinces of Indonesia. Province boundaries are from Klett and others, 1997. 
Table 1. Key input data for two coalbed gas assessment units (AUs) in the Kutei and Barito Basin Provinces of Indonesia.

$[\%$, percent; EUR, estimated ultimate recovery per well; BCFG, billion cubic feet of gas. Well drainage area, success ratio, and EUR are defined partly using U.S. coalbed gas analogs. Shading indicates not applicable]

\begin{tabular}{|c|c|c|c|c|}
\hline \multirow{2}{*}{ Assessment input data-Continuous AU } & \multicolumn{4}{|c|}{ Kutei Neogene Coalbed Gas AU } \\
\hline & Minimum & Mode & Maximum & Calculated mean \\
\hline Potential production area of AU (acres) & 800 & $5,121,000$ & $10,242,000$ & $5,121,267$ \\
\hline Average drainage area of wells (acres) & 40 & 80 & 120 & 80 \\
\hline Success ratio $(\%)$ & 10 & 50 & 90 & 50 \\
\hline Average EUR (BCFG) & 0.08 & 0.2 & 0.35 & 0.206 \\
\hline AU probability & 1.0 & & & \\
\hline \multirow{2}{*}{ Assessment input data-Continuous AU } & \multicolumn{4}{|c|}{ Barito Neogene Coalbed Gas AU } \\
\hline & Minimum & Mode & Maximum & Calculated mean \\
\hline Potential production area of AU (acres) & 800 & $3,032,500$ & $6,065,000$ & $3,032,767$ \\
\hline Average drainage area of wells (acres) & 40 & 80 & 120 & 80 \\
\hline Success ratio $(\%)$ & 10 & 50 & 90 & 50 \\
\hline Average EUR (BCFG) & 0.08 & 0.2 & 0.35 & 0.206 \\
\hline AU probability & 1.0 & & & \\
\hline
\end{tabular}

Table 2. Results for two coalbed gas assessment units (AUs) in the Kutei and Barito Basin Provinces of Indonesia.

[BCFG, billion cubic feet of gas; NGL, natural gas liquids; MMBNGL, million barrels of natural gas liquids. Results shown are fully risked estimates. F95 represents a 95-percent chance of at least the amount tabulated; other fractiles are defined similarly. Fractiles are additive under the assumption of perfect positive correlation. Shading indicates not applicable]

\begin{tabular}{|c|c|c|c|c|c|c|c|c|c|c|}
\hline \multirow{3}{*}{$\begin{array}{l}\text { Total petroleum systems } \\
\text { and assessment units (AUs) }\end{array}$} & \multirow{3}{*}{$\begin{array}{c}\text { AU } \\
\text { probability }\end{array}$} & \multirow{3}{*}{$\begin{array}{c}\text { Accumulation } \\
\text { type }\end{array}$} & \multicolumn{8}{|c|}{ Total undiscovered resources } \\
\hline & & & \multicolumn{4}{|c|}{ Gas (BCFG) } & \multicolumn{4}{|c|}{ NGL (MMBNGL) } \\
\hline & & & F95 & F50 & F5 & Mean & F95 & F50 & F5 & Mean \\
\hline \multicolumn{11}{|c|}{ Kutei Neogene Coal Total Petroleum System } \\
\hline Kutei Neogene Coalbed Gas AU & 1.0 & Coalbed gas & 1,596 & 6,049 & 14,323 & 6,753 & 0 & 0 & 0 & 0 \\
\hline \multicolumn{11}{|c|}{ Barito Neogene Coal Total Petroleum System } \\
\hline Barito Neogene Coalbed Gas AU & 1.0 & Coalbed gas & 929 & 3,573 & 8,436 & 3,985 & 0 & 0 & 0 & 0 \\
\hline Total undiscovered continuous resources & & & 2,525 & 9,622 & 22,759 & 10,738 & 0 & 0 & 0 & 0 \\
\hline
\end{tabular}

\section{References Cited}

Adhi, R.N.; Pujobroto, A.; Gurusinga, C.K.-K.; Kuntjara, U.; Sunuhadi, D.N.; Kasbani; Sumarna, N.; Sumaatmadja, E.R.; Kusdarto; Zulfikar; Ishkandar; and Wahyuningsih, R., comps., 2004, National resources and reserves of mineral, coal, and geothermal: Indonesian Directorate General of Geology and Mineral Resources, Special Publication No. $103,130 \mathrm{p}$

Davis, R.C., Noon, S.W., and Harrington, J., 2007, The petroleum potential of Tertiary coals from western Indonesia - Relationship to mire type and sequence stratigraphic setting: International Journal of Coal Geology, v. 70, nos. 1-3, p. 35-52.

De Man, E., Gantyno, A., Huang, S., Petersen, K., Saferi, E., Widiarti, R., Wertanen, S., and Rahardjanto, S., 2012, CBM operational lessons learned-Barito Basin, Indonesia, in 36th Annual Convention of the Indonesian Petroleum Association, Jakarta, Indonesia, May 23-25, 2012, Proceedings: Indonesian Petroleum Association, Paper IPA12-E-194, 20 p.

Flores, R.M., 2004, Coalbed methane in the Powder River Basin, Wyoming and MontanaAn assessment of the Tertiary-Upper Cretaceous Coalbed Methane Total Petroleum System, chap. 2 of USGS Powder River Basin Province Assessment Team, Total petroleum system and assessment of the coalbed gas in the Powder River Basin Province, Wyoming and Montana: U.S. Geological Survey Digital Data Series DDS-69-C, 1 CD-ROM

Friederich, M.C., Moore, T.A., and Flores, R.M., 2016, A regional review and new insights into SE Asian Cenozoic coal-bearing sediments-Why does Indonesia have such extensive coal deposits?: International Journal of Coal Geology, v. 166, p. 2-35.

Haris, A., Mujiantoro, A., and Kurniawan, R.E., 2010, Evaluation of coal bed methane potential of Bentian Besar, Kutei Basin, in 34th Annual Convention and Exhibition, Jakarta, Indonesia, May 18-20, 2010, Proceedings: Indonesian Petroleum Association, Paper IPA10-G-139, $10 \mathrm{p}$

Klett, T.R., Ahlbrandt, T.S., Schmoker, J.W., and Dolton, G.L., 1997, Ranking of the world's oil and gas provinces by known petroleum volumes: U.S. Geological Survey Open-File Report 97-463, 1 CD-ROM

\section{Assessment Team}

Christopher J. Schenk, Tracey J. Mercier, Phuong A. Le, Marilyn E. Tennyson, Thomas M. Finn, Michael E. Brownfield, Kristen R. Marra, Stephanie B. Gaswirth, Heidi M. Leathers-Miller, Janet K. Pitman, and Ronald M. Drake II

\section{For More Information}

Assessment results are also available at the USGS Energy Resources Program website at https://energy.usgs.gov.
Moss, S.J., and Chambers, J.L.C., 1999, Tertiary facies architecture in the Kutai Basin, Kalimantan, Indonesia: Journal of Asian Earth Sciences, v. 17, nos. 1-2, p. 157-181.

Paterson, D.W., Bachtiar, A., Bates, J.A., Moon, J.A., and Surdam, R.C., 1997, Petroleum system of the Kutei Basin, Kalimantan, Indonesia, in Conference on Petroleum Systems of SE Asia and Australasia, Jakarta, Indonesia, May 21-23, 1997, Proceedings: Indonesian Petroleum Association, Paper IPA97-OR-35, p. 709-726.

Pramudhita, B.A.; Siregar, B.S.A.; Tanjung, H.; Faris, M.; Indrajaya, R.; Satrio; and Kambu, Y., 2009, Palynology analysis and coal characterization-A preliminary study for CBM prospectivity of Balikpapan Formation, Kutei Basin, in 33rd Annual Convention of the Indonesian Petroleum Association 2009, Jakarta, Indonesia, May 5-7, 2009, Proceedings: Indonesian Petroleum Association, Paper IPA-SG-040, 10 p.

Putra, R.R., Larasati, D., Ardi, S., Fiqih, F.M., Ramdani, H., Widarto, D., Guntoro, A., and Usman, A., 2016, Fault facies identification to determine optimum coal cleat occurence [sic] as coal bed methane reservoir potential, case studies - Warukin coal bearing formation (WCBF), Barito Basin, south Kalimantan, Indonesia, in Unconventional Resources Technology Conference, San Antonio, Texas, August 1-3, 2016, Proceedings: Society of Exploration Geophysicists, American Association of Petroleum Geologists, Society of Petroleum Engineers, URTeC 2460930, 17 p., accessed May 17, 2018, at http://archives. datapages.com/data/urtec/2016/2460930.pdf.

Sapiie, B., Rifiyanto, A., and Perdana, L.A., 2014, Cleats analysis and CBM potential of the Barito Basin, south Kalimantan, Indonesia: American Association of Petroleum Geologists, Search and Discovery Article No. 10653, 19 p., accessed May 17, 2018, at http:// www.searchanddiscovery.com/pdfz/documents/2014/10653sapiie/ndx_sapiie.pdf.html.

Satyana, A.H., Nugroho, D., and Surantoko, I., 1999, Tectonic controls on the hydrocarbon habitats of the Barito, Kutei, and Tarakan Basins, eastern Kalimantan, Indonesia-Major dissimilarities in adjoining basins: Journal of Asian Earth Sciences, v. 17, nos. 1-2, p. 99-122.

Widodo, S., Oschmann, W., Bechtel, A., Sachsenhofer, R.F., Anggayana, K., and Puettmann, W., 2010, Distribution of sulfur and pyrite in coal seams from Kutai Basin (East Kalimantan, Indonesia) - Implications for paleoenvironmental conditions: International Journal of Coal Geology, v. 81, no. 3, p. 151-162.

Witts, D., Hall, R., Morley, R.J., and BouDagher-Fadel, M.K., 2011, Stratigraphy and sediment provenance, Barito Basin, southeast Kalimantan, in 35th Annual Convention and Exhibition, Jakarta, Indonesia, May 18-20, 2011, Proceedings: Indonesian Petroleum Association, Paper IPA11-G-054, 18 p. 